\title{
Survey of mutations in prolificacy genes in Santa Ines and Morada Nova sheep
}

\author{
[Pesquisa de mutações em genes da prolificidade em ovelhas Santa Inês e Morada Nova] \\ G.M.L. Holanda ${ }^{1}$, J.C. Oliveira ${ }^{2}$, D.M.F. Silva ${ }^{3}$, S.S.N. Rocha ${ }^{3 *}$, V. Pandolfi,
M. Adrião ${ }^{3}$, A. Wischral \\ ${ }^{1}$ Agência de Defesa Agropecuária de Pernambuco- ADAGRO - Recife, PE \\ ${ }^{2}$ Instituto Agronômico de Pernambuco - IPA - Recife -PE \\ ${ }^{3}$ Universidade Federal Rural de Pernambuco - UFRPE- Recife, PE \\ ${ }^{4}$ Universidade Federal de Pernambuco - UFPE - Recife, PE
}

\begin{abstract}
Polymorphisms in the BMP-15 gene related to Galway $\left(F e c \mathrm{X}^{\mathrm{G}}\right)$ and Inverdale $\left(F e c \mathrm{X}^{\mathrm{I}}\right)$ and in the BMPR-1B gene known as Booroola $(F e c B)$ mutations were investigated using the Polymerase Chain Reaction - Restriction Fragment Length Polymorphism (PCR-RFLP) method, on sheep from the breeds Santa Inês $(n=574)$ and Morada Nova $(n=282)$. DNA was extracted and amplified through PCR with specific primers that introduced a restriction site in association with the mutation. The PCR products were submitted to endonucleases. The experiment found no $F e c \mathrm{X}^{\mathrm{G}}$ and $F e c \mathrm{X}^{\mathrm{I}}$ mutations. Six samples of animals with multiple offspring/birth history presented polymorphism for $F e c \mathrm{~B}$ similar to control samples, but this pattern was not confirmed by nucleotide sequencing. Although the absence of these mutations in the studied breeds, other factors related to prolificacy should be investigated to explain the inherent prolificity mechanisms.
\end{abstract}

Keywords: Galway, Inverdale, Booroola, sheep, prolificacy gene, Santa Inês, Morada Nova

\section{RESUMO}

Polimorfismos Galway $\left(\mathrm{Fec} X^{G}\right)$ e Inverdale $\left(\mathrm{Fec} X^{I}\right)$, relacionados ao gene BMP-15, e Booroola $(\mathrm{Fec} B)$, localizado no gene BMPR-1B, foram investigados usando-se a técnica de reação em cadeia da polimerase - polimorfismo de comprimento de fragmentos de restrição (PCR-RFLP), em ovelhas Santa Inês $(n=574)$ e Morada Nova (n=282). O DNA foi extraído e amplificado por PCR com iniciadores específicos, que introduziram um sítio de restrição associado à mutação, em seguida os amplicons foram submetidos à ação de endonucleases. Não foram observadas as mutações $\mathrm{Fec} X^{G} e$ Fec $X^{I}$ nas amostras estudadas. Amostras de seis animais com histórico de partos gemelares apresentaram polimorfismo para $\mathrm{Fec} B$ semelhantes às amostras controle, mas esse padrão não foi confirmado pelo sequenciamento de nucleotídeos. Apesar da ausência dessas mutações nos animais das raças estudadas, outros fatores relacionados à prolificidade devem ser pesquisados para explicar os mecanismos da alta prolificidade desses animais.

Palavras-chave: Galway, Inverdale, Booroola, ovelha, gene da prolificidade, Santa Inês, Morada Nova

\section{INTRODUCTION}

An increase in the production efficiency in herds related to gains in prolificacy is of considerable economic importance. The breed known as Santa Ines was formed naturally over the years through breeding of the native matrix with the breeds Bergamácia, Morada Nova and Somalis. The

Recebido em 17 de agosto de 2016 Aceito em 10 de outubro de 2016

*Autor para correspondência (corresponding author)

E-mail: suzanasnr@gmail.com
Santa Ines breed has considerable influence in the formation of commercial sheep herds in Brazil. Among those that formed the Santa Ines breed, the Morada Nova breed is cited as one of the most prolific, with its presence owing to a few persistent sheep breeders.

The discovery of mutations related to prolificacy in breeds and lineages has helped drive genetic improvement programs aimed at increasing prolificacy in herds. 
The Booroola mutation was found in the highlyconserved domain of intracellular serinetreonine-kinase of bone morphogenetic protein receptor 1B (BMPR-1B), characterized by a single change in nucleotides $A$ to $G$ (Q249R) resulting in a protein related with prolificacy phenotype in Merino-Booroola sheep (Mulsant et al., 2001, Souza et al., 2001, Wilson et al., 2001). The effect of this mutation, located in the autosomal chromosome 6 , is addictive in the ovulatory rate. The alleles $F e c \mathrm{~B}^{\mathrm{BB}}$ and $F e c \mathrm{~B}^{\mathrm{B}+}$ are related to high prolificacy and the allele $F e c \mathrm{~B}^{++}$is considered wild phenotype (Davis et al., 2002).

Other prolific ovine lineages have been studied and mutations in the gene of bone morphogenetic protein 15 (BMP-15) were implicated (Galloway et al., 2000, Liao et al., 2004). The BMP-15 consists of a growth factor (a member of the superfamily TGF $\beta$ ), which is specifically expressed in oocytes. These proteins are multifunctional and control the growth and differentiation of various cells type, having a critical role on the mammal fertility, including growth factors as Growth Differentiation Factor 9 (GDF9), localized in oocytes, and BMP-15 having receptors expressed in ovaries (Wilson et al., 2001). The BMP-15 regulates granulose cell proliferation and differentiation, promoting mitosis in the follicle-stimulating hormone independent phase, and inhibiting the expression of FSH receptors as well as events dependent on this hormone, thereby promoting follicle growth and avoiding premature luteinization (Otsuka et al., 2001, Otsuka et al., 2000). The BMP-15 inheritance mechanisms in sheep were revealed in studies carried out by Davis et al (1991) who pointed to an inheritance linked to the $X$ chromosome for this trait, thereby creating the opportunity for studies on ovarian physiology and fertility in other mammals (Otsuka et al., 2001).

The BMP-15 gene was denominated FecX (Galloway et al., 2000), and the Fec $\mathrm{X}^{\mathrm{G}}$ gene mutation (Galway lineage) is characterized by an exchange of nucleotides (Q239Ter) that results in the insertion of a premature stopping point in the transcription of the protein. In heterozygosis, this mutation has been associated to an increase in ovulation in Cambridge and Belclare sheep (Hanrahan et al., 2004).
Another mutation in this gene was observed in Inverdale lineage in prolific Romney sheep (Davis et al., 1991). The Inverdale mutation is characterized by a single change of nucleotides resulting in different aminoacids (V31N) (Liao et al., 2003). Rams bearing the mutation $\left(F e c \mathrm{X}^{\mathrm{IY}}\right)$ breed with heterozygote females $\left(F e c \mathrm{X}^{\mathrm{I}+}\right)$ produced homozigote daughters $\left(F e c \mathrm{X}^{\mathrm{II}}\right)$ with no functional ovaries, while heterozygote ones presented one more ovulation than wild females $\left(\right.$ Fec $\left.\mathrm{X}^{++}\right)$(Davis et al., 1992).

This increase in ovulation rate may be due to the reduced action of BMP-15 as a FSH inhibitor and consequently greater number of follicle producing estrogen, with LH receptors (Otsuka et al., 2001).

According to Davis (2004) the commercial use of markers for this trait consists of retaining prolific female offspring resulted of breeding between rams with this mutation and ewes without it.

The existence of sheep lineages with high prolificacy, which exhibit mutations in specific genes, raises the question as to whether other prolific breeds, including native breeds, have a heretofore unknown genetic proximity. As the $F e c \mathrm{X}^{\mathrm{G}}$ mutation has been found in unrelated breeds (Belclare/Cambridge and Small-Tailed Han) (Davis et al., 2006b), it is interesting to study the possible existence of FecX ${ }^{\mathrm{G}}, F e c \mathrm{X}^{\mathrm{I}}$ or $F e c \mathrm{~B}^{\mathrm{B}}$ in other prolific breeds, such as Santa Inês and Morada Nova, using these markers.

Thus, the aim of the present study was to detect polymorphism in a single nucleotide from the BMPR-1B $\left(F e c \mathrm{~B}^{\mathrm{B}}\right)$ and BMP-15 $\left(F_{e c \mathrm{X}^{\mathrm{G}}}\right.$ and $\left.F e c \mathrm{X}^{\mathrm{I}}\right)$ genes in sheep from the Santa Inês and Morada Nova breeds, which have considerable importance in Brazilian production.

\section{MATERIALS AND METHODS}

Eight hundred and fifty six animals were selected from the semi-arid region of the Brazilian Northeast. All animals had at least three parturitions, divided into groups of one offspring/parturition (Santa Inês, $n=393$ and Morada Nova, $\mathrm{n}=170)$ or two or more offspring/parturition (Santa Inês, $\mathrm{n}=181$ and Morada Nova, $n=112)$. Blood samples $(5 \mathrm{~mL})$ were collected from each sheep, with sodium 
citrate used as anticoagulant. The genomic DNA was extracted from the leukocytes using the modified phenol-chloroform method (Sambrook et al., 1989) and stored at a temperature of $-20^{\circ} \mathrm{C}$.

Methodology that amplifies the region of the gene using primers with single mismatches to generate products with forced restriction site in association of mutation was employed to identify mutation.

The primers used to identify the $F e c \mathrm{X}^{\mathrm{G}}$ mutation inserted a restriction site to HinfI (G/ACT) in animals bearing no mutation - F: 5'CACTGTCTTCTTGTTAC TGTATTTCAATGAGAC3' and R: 5'GATGCAATACTGCCTGCTTG3' (Hanrahan et al., 2004).

The amplification conditions were: denaturation at $95^{\circ} \mathrm{C} / 5 \mathrm{~min}$, followed by 30 denaturation cycles at $95^{\circ} \mathrm{C} / 45 \mathrm{sec}$, annealing at $63^{\circ} \mathrm{C} / 45 \mathrm{sec}$ and extension at $72^{\circ} \mathrm{C} / 1 \mathrm{~min}$, with a final extension at $72^{\circ} \mathrm{C} / 10 \mathrm{~min}$. DNA digestion was performed for a final volume of $15 \mu \mathrm{L}(8.5 \mu \mathrm{L}$ of ultrapure water, $1.5 \mu \mathrm{L}$ of enzyme buffer and 10 $\mathrm{U}$ of the Hinf I enzyme and $5 \mu \mathrm{l}$ of the amplified DNA (PCR product). The digested DNA was visualized in $8 \%$ polyacrylamid gel. The individuals of the wild type $\left(F e c \mathrm{X}^{++}\right)$had fragments of $111 \mathrm{bp}$ and $30 \mathrm{bp}$; heterozygotic individuals $\left(F e c \mathrm{X}^{\mathrm{G}+}\right)$ had fragments of $141 \mathrm{bp}$, $111 \mathrm{bp}$ and $30 \mathrm{bp}$; and homozygotic individuals $\left(F e c \mathrm{X}^{\mathrm{GG}}\right)$ only had the uncut fragment of $141 \mathrm{bp}$.

To study this mutation were used primers that introduced a restriction site for the endonuclease XbaI; 5'GAAGTAACCAGTGTTCCCTCCACCCTTTTCT 3' e 5'-CATGATTGGGAGAATTGAGACC-3' (Davis et al., 2006b).

The PCR reactions were performed in $20 \mu \mathrm{L}$ final volume, containing: $2,5 \mu \mathrm{L} 10 \mathrm{x}$ PCR buffer; $3,0 \mu \mathrm{L}$ of $50 \mathrm{mM} \mathrm{MgCl}{ }_{2} 1 \mu \mathrm{L}$ of each primer (10 pmol), $3,5 \mu \mathrm{L}$ of $2 \mathrm{mM}$ dNTP; $0,2 \mu \mathrm{L}$ Taqpolimerase $(5 \mathrm{U} / \mu \mathrm{L}), 11,8 \mu \mathrm{L}$ ultrapure water and $2,0 \mu \mathrm{L}$ of DNA (50ng). The conditions of amplification were: 35 cycles of denaturation at $94^{\circ} \mathrm{C} / 30 \mathrm{sec}$, annealing at $60^{\circ} \mathrm{C} / 40 \mathrm{sec}$ and e extension at a $70^{\circ} \mathrm{C} / 30 \mathrm{sec}$, and a final extension at $72^{\circ} \mathrm{C} / 4 \mathrm{~min}$. The amplicon was submitted to endonuclease $X b a \mathrm{I}$ cut $(8,5 \mu \mathrm{L}$ ultrapure water, $1,5 \mu \mathrm{L}$ of buffer and $10 \mathrm{U}$ XbaI I). Products containing the Fec $\mathrm{X}^{\mathrm{I}}$ mutation yield 124 bp and 30 bp fragments, whilst non-carrier products remain uncut at $154 \mathrm{bp}$.

As the positive control for the $F e c \mathrm{~B}$ mutation, DNA samples of Booroola animals were used (kindly provided by Dr. Carlos Jose Hoff de Souza/Embrapa Sul).

The primers inserted a restriction site to AvaII (G/GACC) in animals bearing the Booroola mutation - F: 5'CCAGAGGAACAATAGCAAAGCAAA; $R: \quad 5^{\prime}-$ CAAGATGTTTTCATGCCTCATCAACACGGTC

(Davis et al., 2002). The amplification conditions were initial denaturation at $94^{\circ} \mathrm{C} / 2 \mathrm{~min}, 8$ cycles of denaturation at $94^{\circ} \mathrm{C} / 15 \mathrm{sec}$, annealing at $62^{\circ} \mathrm{C} / 30 \mathrm{sec}$, and extension at $72^{\circ} \mathrm{C} / 30 \mathrm{sec}$, followed by 30 cycles of denaturation at $94^{\circ} \mathrm{C} / 15$ sec, annealing at $60^{\circ} \mathrm{C} / 30 \mathrm{sec}$, and extension at $72^{\circ} \mathrm{C} / 15 \mathrm{sec}$, with final temperature at $8^{\circ} \mathrm{C}$. The PCR product was digested with AvaII $(8.5 \mu \mathrm{L}$ of ultrapure water, $0.8 \mathrm{U}$ of enzyme, $1.5 \mu \mathrm{L}$ of buffer and $5 \mu \mathrm{L}$ of DNA). After electrophoresis, no digested fragment presented $190 \mathrm{bp}$, and digested fragment showed $160 \mathrm{bp}$ and $30 \mathrm{bp}$. Heterozygote animals should present both fragments of 30, 160 and $190 \mathrm{bp}$.

The products of endonuclease reactions were analyzed in $2 \%$ agarose gel using blue green loading dye I (LGC- Biotecnologia). The data on the bands found in each group of sheep breed, for each mutation, were analyzed for frequency and related to the prolific phenotype.

The amplified fragments of BMPR-1B were separated on "Low Melting Point" 1,5\% agarose gel at $4 \mathrm{v} / \mathrm{cm}$ for 2 hours and re-extracted using GFX PCR DNA and Gel Band Purification Kit (GE Healthcare), according to manufacturer instructions. Each DNA fragment was ligated into the pGEM-T Easy vector (Promega, Madison, WI USA) at the ratio of $3: 1$ (insert:vector), at $4^{\circ} \mathrm{C}$ overnight, according to the manufacturer's instructions. The fragment was then transformed into Escherichia coli EletroMAX DH10B competent cell (Invitrogen) using a micro pulser electroporator ECM 399 Electroporation System (BTX Harvard Apparatus, Cat 45-0000). Positive clones of transformed cells were identified based on bluewhite selection of recombinant vectors, and confirmed by colony PCR using vector primers 
(T7 and Sp6) showing the $190 \mathrm{bp}$ insert fragments upon gel analysis. Three positive clones of each genotype (biological triplicates) were selected for mini preparation of plasmid DNA according to modified alkaline lysis plasmid mini-prep method (Sambrook et al., 1989). The authenticity of the fragments was confirmed by sequencing of insert-containing plasmids performed from both directions for three times using the BigDye Terminator v3.1 Cycle Sequence Kit (Applied Biosystems, Foster City, CA-USA), in an Automatic ABI 3130XL sequencer (Applied Biosystems, Foster City, CA-USA).

The chromatograms were passed through a basecalling process using phred (Ewing et al., 1998), which assigned quality values above 20 to the bases. Sequences alignment and generation of each consensus was performed by using Clustal $\mathrm{W}$, running under BioEdit, version 5.0.9 (Hall, 1999). The consensus sequence respective to each genotype was analyzed by Blast (Basic Local Alignment Search Tool) against nucleotide collection, that consisted of GenBank, EMBL, DDBJ, PDB and RefSeq sequences, using nucleotide sequences (BlastN).

\section{RESULTS}

The Santa Inês and Morada Nova ovine breeds have been reported to be prolific in the semi-arid region conditions of northeastern Brazil. In the visited herds, 39,7 \% of Morada Nova females had at least one multiple-offspring birth, and $31,5 \%$ of Santa Inês females had scores of multiple-offspring births. The prolific index of these animals was 2.44 and 2.13 for the Santa Inês and Morada Nova breeds, respectively (Table 1).

Table 1. Mean number of offspring/birth for Morada Nova and Santa Inês breeds with a history of multiple-offspring births

\begin{tabular}{lll}
\hline & Breed & \\
\cline { 2 - 3 } & $\begin{array}{l}\text { Morada } \\
\text { Nova }\end{array}$ & $\begin{array}{l}\text { Santa } \\
\text { Inês }\end{array}$ \\
\hline $\begin{array}{l}\text { Total animals } \\
\text { No. of animals with } \\
\text { multiple offspring/birth }\end{array}$ & 282 & 574 \\
$\begin{array}{l}\text { Average of offspring/birth } \\
\text { (multiples) }\end{array}$ & 2.13 & 181 \\
\hline
\end{tabular}

No mutations referring to the Galway $F e c \mathrm{X}^{\mathrm{G}}$ gene were found in the studied breeds. PCRRFLP revealed that all wild bands were cut by the Hinf I enzyme (G/ACT), resulting in fragments of $111 \mathrm{bp}$, which characterizes an absence of mutation for the $F e c \mathrm{X}^{\mathrm{G}}$ gene.

All analyzed samples for $F e c^{I}$ mutation showed uncut fragments after PCR-RFLP, in this case characterizing the absence of Inverdale mutation.

Otherwise, the $F e c B$ mutation revealed polymorphism in six samples from Santa Inês females with litter size of 2,49 in average. In these samples was observed two bands (190 and $160 \mathrm{bp}$ ) similar to heterozygote positive control (Figure 1).

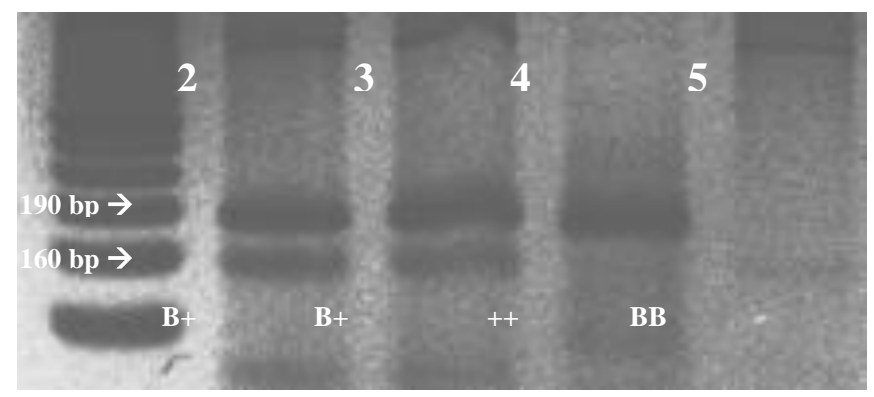

Figure 1. PCR products digested with $A v a$ II. 1: DNA ladder 50 bp; 2: Santa Inês heterozygote (B+); 4: wild genotype (++); 3 and 5: positive controls for Booroola-Merino, B+ (190 and $160 \mathrm{bp})$ and BB (160 $\mathrm{bp})$, respectively. 
To confirm this mutation, the amplified fragments were submitted to cloning and sequencing, but the sequences did not show the expected change in the nucleotide (A-G), that was present in the positive control.

\section{DISCUSSION}

This study was performed in order to search mutations in the BMP15 and BMPR-1B genes in prolific Santa Inês and Morada Nova ewes. Due to the extensive breeding system, breeders do not prize prolific females, citing management difficulties in the pasture breeding system. Thus, there is a need to offer further information to breeders with regard to the benefits in terms of production gains when there is efficient management of prolific females. Although this trait has not been well accepted in the extensive breeding system, 39.7\% of the Morada Nova, and $31.3 \%$ of Santa Inês females had history of at least one multiple-offspring birth. Thus, prolificacy is an inherent characteristic of these breeds.

In the present study, the PCR-RFLP method cited by Hanrahan et al. (2004) was employed for the investigation of the mutation referring to the BMP-15 gene $\left(F e c \mathrm{X}^{\mathrm{G}}\right.$ loci), which was not found in the Santa Inês and Morada Nova breeds. Although the relevance of these studies, the results are conflicting. These mutations were not found during a study performed in 21 of the most prolific breeds and lineages in the world. Among these breeds, the Fec $\mathrm{X}^{\mathrm{I}}$ mutation (Inverdale) was not observed in the Small-Tailed Han, in which the Fec B mutation was detected (Davis et al., 2006a). However, studies carried in China described the Asian Small-Tailed Han breed as having simultaneous mutations $(F e c \mathrm{~B}$ and $\left.F e c \mathrm{X}^{\mathrm{G}}\right)(\mathrm{Chu}$ et al., 2007).

The occurrence of the Booroola gene was reported in Indian sheep of the Kendrapada breed with a history of prolificacy when investigating the BMPR-1B (FecB) and BMP15 $\left(F e c \mathrm{X}^{\mathrm{G}}\right)$ simultaneously (Kumar et al., 2008). As in the present study; however, no mutations related to the Fec $\mathrm{X}^{\mathrm{G}}$ gene (Galway) were found.

Regarding studies carried out in Brazil on larger genes linked to prolificacy, a new single nucleotide polymorphism (SNP) located in the position 345 inside GDF-9 gene in the Santa Inês breed, that was named $F e c \mathrm{G}^{\mathrm{E}}$, may be related to the high ovulation frequency that is characteristic of this breed (Silva et al., 2010). No studies have been carried out investigating the $F e c \mathrm{X}$ gene in the breeds analyzed here and no surveys have been noticed for this gene in any Brazilian breeds. Therefore, there is a need for further studies with the aim of investigating the possible existence of other mutations related to the prolificacy of the Santa Inês breeds as well as its precursors, such as the Morada Nova breed.

As no mutations related to the $F e c \mathrm{X}^{\mathrm{G}}$ gene were found in the present study, the use of surveys related to these mutations as a marker for prolificacy with the methodology employed here is not an adequate tool for commercial use in improvement programs for this trait in the breeds studied. However, studies on phylogeny in sheep based on the investigation of common polymorphisms between breeds or lineages should be taken into consideration. For example, the Booroola gene has been chosen for studies on binding maps. Thus, such studies on breeds of Brazilian sheep with a history of prolificacy are important.

Binding maps are an important tool for the identification of genes associated to production traits in large animals. Selection programs for domestic animals based on phenotype measurements have improved, and an understanding of the structure and function of the genomes of domestic animals offered by genetic maps allows the opportunity to identify the variations responsible for the differences in production performance. Molecular markers linked to inheritable traits will enable a more efficient selection of elite animals and will eventually allow the identification of genes that influence genetic expression (Crawford et al., 1994).

In the other hand, more recently, mRNA assays performed to study the gene expression in ovaries of prolific animals, have demonstrated the relationship between the number of antral follicles/ovarian mass and the abundance of BMP15 mRNA in goats follicles (Pramod et al., 2013).

Despite the absence of the studied mutations in the Santa Inês and Morada Nova breeds, which have a history of prolificacy, other markers 
should be investigated that are particular to these breeds and may explain the passing down of this trait to descendents.

\section{ACKNOWLEDGMENTS}

This study was conducted with the financial support of FACEPE and a CAPES/FACEPE grant. The authors are grateful to the sheep breeders of Northeastern Brazil, especially those in the states of Paraíba (Mogeiro), Pernambuco (Brejo da Madre de Deus, Vicência, Pesqueira, Serra Talhada and Triunfo) and Ceará (Sobral), who conceded their animals for the acquisition of the material used in this study.

\section{REFERENCES}

CHU, M.X.; LIU, Z.H.; JIAO, C.L. et al. Mutations in BMPR-IB and BMP-15 genes are associated with litter size in small tailed han sheep (Ovis aries). J. Anim. Sci., v.85, p.598-603, 2007.

CRAWFORD, A.M.; MONTGOMERY, G.W.; PIERSON, C.A. et al. Sheep linkage mapping: nineteen linkage groups derived from the analysis of paternal half-sib families. Genetics, v.137, p.573-579, 1994.

DAVIS, G.H.; BALAKRISHNAN, L.; ROSS, I.K. et al. Investigation of the Booroola (FecB) and Inverdale $(\mathrm{FecX}(\mathrm{I}))$ mutations in 21 prolific breeds and strains of sheep sampled in 13 countries. Anim. Reprod. Sci., v.92, p.87-96, $2006 a$.

DAVIS, G.H.; FARQUHAR, P.A.; O'CONNELL, A.R. et al. A putative autosomal gene increasing ovulation rate in Romney sheep. Anim. Reprod. Sci., v.92, p.65-73, 2006 b.

DAVIS, G.H.; GALLOWAY, S.M.; ROSS, I.K. et al. DNA tests in prolific sheep from eight countries provide new evidence on origin of the Booroola (FecB) mutation. Biol. Reprod., v.66, p.1869-1874, 2002.

DAVIS, G.H.; MCEWAN, J.C.; FENNESSY, P.F. et al. Evidence for the presence of a major gene influencing ovulation rate on the $\mathrm{X}$ chromosome of sheep. Biol. Reprod., v.44, p.620-624, 1991.
DAVIS, G.H.; MCEWAN, J.C.; FENNESSY, P.F. et al. Infertility due to bilateral ovarian hypoplasia in sheep homozygous (FecXI FecXI) for the Inverdale prolificacy gene located on the X chromosome. Biol. Reprod., v.46, p.636-640, 1992.

DAVIS, G.H. Fecundity genes in sheep. Anim. Reprod. Sci. 82-83, 247-253, 2004.

EWING, B.; HILLIER, L.; WENDL, M.C.; GREEN, P. Base-calling of automated sequencer traces using phred. I. Accuracy assessment. Genome Res., v.8, p.175-185, 1998.

GALLOWAY, S.M.; MCNATTY, K.P.; CAMBRIDGE, L.M. et al. Mutations in an oocyte-derived growth factor gene (BMP15) cause increased ovulation rate and infertility in a dosage-sensitive manner. Nat. Genet., v.25, p.279-283, 2000.

HALL, T.A. Bioedit: a user-friendly biological sequence alingment editor and analysis program for Windows 95/98/NT. Nucleic Acids Symp. Ser., v.41, p.6, 1999.

HANRAHAN, J.P.; GREGAN, S.M.; MULSANT, P. et al. Mutations in the genes for oocyte-derived growth factors GDF9 and BMP15 are associated with both increased ovulation rate and sterility in Cambridge and Belclare sheep (Ovis aries). Biol. Reprod., v.70, p.900-909, 2004.

KUMAR, S.; MISHRA, A.K.; KOLTE, A.P. et al. Screening for Booroola (FecB) and Galway (FecXG) mutations in Indian sheep. Small Ruminant Res., v.80, p.5, 2008.

LIAO, W.X.; MOORE, R.K.; OTSUKA, F.; SHIMASAKI, S. Effect of intracellular interactions on the processing and secretion of bone morphogenetic protein-15 (BMP-15) and growth and differentiation factor-9. Implication of the aberrant ovarian phenotype of BMP-15 mutant sheep. J. Biol. Chem., v.278, p.37133719, 2003.

LIAO, W.X.; MOORE, R.K.; SHIMASAKI, S. Functional and molecular characterization of naturally occurring mutations in the oocytesecreted factors bone morphogenetic protein-15 and growth and differentiation factor-9. J. Biol. Chem., v.279, p.17391-17396, 2004. 
MULSANT, P.; LECERF, F.; FABRE, S. et al. Mutation in bone morphogenetic protein receptor-IB is associated with increased ovulation rate in Booroola Merino ewes. Proc. Natl. Acad. Sci. U.S.A., v.98, p.5104-5109, 2001.

OTSUKA, F.; YAMAMOTO, S.; ERICKSON, G.F.; SHIMASAKI, S. Bone morphogenetic protein-15 inhibits follicle-stimulating hormone (FSH) action by suppressing FSH receptor expression. J. Biol. Chem., v.276, p.1138711392, 2001.

OTSUKA, F.; YAO, Z.; LEE, T. et al. Bone morphogenetic protein-15. Identification of target cells and biological functions. J. Biol. Chem., v.275, p.39523-39528, 2000.

PRAMOD, R.; SHARMA, S.; SINGHI, A. et al. Differential ovarian morphometry and follicular expression of BMP15, GDF9 and BMPR1B influence the prolificacy in goat. Reprod. Domest. Anim., v.48, p.803-809, 2013.

SAMBROOK, J.; FRITSCH, E.F.; MANIATIS, T. Molecular cloning: a laboratory manual. 2.ed. New York: Cold Spring Harbor Laboratory Press, 1989. v.3, 253p.
SILVA, B.D.M.; CASTRO, E.A.; SOUZA, C.J.H. et al. A new polymorphism in the Growth and Differentiation Factor 9 (GDF9) gene is associated with increased ovulation rate and prolificacy in homozygous sheep. Anim. Genet., v.42, p.4, 2010.

SOUZA, C.J.; MACDOUGALL, C.; CAMPBELL, B.K. et al. The Booroola (FecB) phenotype is associated with a mutation in the bone morphogenetic receptor type 1 B (BMPR1B) gene. J. Endocrinol., v.169, p.1-6, 2001.

WILSON, T.; WU, X.Y.; JUENGEL, J.L. et al. Highly prolific Booroola sheep have a mutation in the intracellular kinase domain of bone morphogenetic protein IB receptor (ALK-6) that is expressed in both oocytes and granulosa cells. Biol. Reprod., v.64, p.1225-1235, 2001. 